\title{
Evaluation of yeasts from Tibetan fermented products as agents for biocontrol of blue mold of Nashi pear fruits
}

\author{
Hao HU, Yang XU, Huang-ping LU, Rui XIAO, Xiao-dong ZHENG ${ }^{\dagger \ddagger}$, Ting YU \\ (Zhejiang Key Laboratory for Agro-Food Processing, Fuli Institute for Food Science, College of Biosystems Engineering and Food Science, \\ Zhejiang University, Hangzhou 310058, China) \\ †E-mail: xdzheng@zju.edu.cn \\ Received June 10, 2014; Revision accepted Dec. 10, 2014; Crosschecked Mar. 27, 2015
}

\begin{abstract}
A total of 20 strains of yeast isolated from Tibetan fermented products were screened for antagonism against blue mold of pear caused by Penicillium expansum. Six isolates that inhibited incidence of postharvest decay by $35 \%$ or more were selected for further screening. Among them, the most effective was Rhodotorula mucilaginosa. The results showed that washed cell suspensions of $R$. mucilaginosa yielded better antagonistic efficacy than unwashed cell-culture mixtures, cell-free culture filtrates, and autoclaved cell cultures. Biocontrol activity improved with increasing concentrations of incubated cells. The best concentration was $1 \times 10^{8} \mathrm{cells} / \mathrm{ml}$, at which the incidence of decay was only $16.7 \%$ after $6 \mathrm{~d}$ of incubation. The germination of conidia of $P$. expansum in vitro was significantly inhibited by both washed cell-suspensions and unwashed cell-culture mixtures. Rapid colonization by yeast at different concentrations showed a relationship between yeast-cell concentration and biocontrol activity. Although the titratable acidity of pear fruits increased after treatment, $R$. mucilaginosa did not affect the total soluble solids or ascorbic acid content. This is the first study to report that the yeast $R$. mucilaginosa from Tibet Autonomous Region of China may have potential as an antagonist to control the postharvest decay of pear fruits.
\end{abstract}

Key words: Biocontrol, Postharvest, Rhodotorula mucilaginosa, Tibetan yeast isolates, Pear doi:10.1631/jzus.B1400162 Document code: A CLC number: $\mathrm{S}_{476}{ }^{+} .9$

\section{Introduction}

The pear (Pyrus spp.) is one of the most important and popular fruits in China (Liu et al., 2013; Yue et al., 2014). During postharvest storage, blue mold is a major disease of pear (Sanderson and Spotts, 1995; Jurick et al., 2010). Currently, the application of synthetic fungicides is the main method adopted to control the disease (Lennox et al., 2004; Sugar and Basile, 2011). However, with the application of postharvest fungicides, the resistance of the pathogen

\footnotetext{
${ }^{\ddagger}$ Corresponding author

* Project supported by the Doctoral Program Foundation of the Ministry of Education of China (No. 20100101110087) and the National Natural Science Foundation of China (No. 30972051)

(DD ORCID: Xiao-dong ZHENG, http://orcid.org/0000-0002-0307-7754; Hao HU, http://orcid.org/0000-0003-3020-1930

(c) Zhejiang University and Springer-Verlag Berlin Heidelberg 2015
}

gradually increases, and fungicidal residues that raise food safety issues for consumers are also of great concern. Therefore, there is an urgent need to explore other methods to replace synthetic fungicides for the control of postharvest diseases of pear (Wilson and Wisniewski, 1989; Wisniewski and Wilson, 1992). The use of microbial antagonists, yeasts in particular, to control postharvest decay is regarded as a promising alternative (Wilson et al., 1991; Spadaro and Gullino, 2004; Sharma et al., 2009).

Among numerous antagonists, antagonistic yeasts show great promise (Zhang et al., 2007; Xu et al., 2008; Wang et al., 2009; 2011; Lutz et al., 2011; Janisiewicz et al., 2014; Lu et al., 2014). Because most yeasts do not produce antibiotics, they are considered to be safer than other kinds of microbial antagonists (Wisniewski et al., 1991). Furthermore, the colonization of fruit wounds by yeasts is rapid 
(Castoria et al., 2005). One of the main mechanisms by which antagonistic yeasts may control postharvest decay is by competing for space and nutrients (Droby et al., 2009; Jamalizadeh, 2011). Finally, many biocontrol yeasts show the ability to be compatible with fungicides and other chemicals (An et al., 2012; Yu et al., 2012; D'Aquino et al., 2013). Antagonistic yeasts have been isolated from soil, fruit surfaces, and fruit wounds (Janisiewicz and Korsten, 2002). Due to the unique geographical environment of Tibet Autonomous Region of China, there has been little research on the use of Tibetan yeasts for the control of postharvest diseases of fruit. Zhao et al. (2012) reported that a Streptomyces sp. was selected to control gummy stem blight. In this study, the yeast Rhodotorula mucilaginosa was selected from Tibetan fermented products, following the screening of twenty yeast isolates for their effectiveness in biocontrol. The aim of this study was to investigate and evaluate the efficacy of $R$. mucilaginosa from Tibet in inhibiting postharvest blue mold decay in pear caused by Penicillium expansum. Although some studies have been conducted on $R$. mucilaginosa as a biocontrol agent (Li et al., 2011; Lutz et al., 2011; Robiglio et al., 2011), this is the first report of $R$. mucilaginosa from Tibet being used as an agent for controlling the blue mold of pear.

\section{Materials and methods}

\subsection{Fruits}

Nashi pear fruits (Pyrus pyrifolia Nak., cultivar "Shuijing"), of uniform ripeness and size and without any apparent damage or infection, were harvested at commercial maturity in Hangzhou, Zhejiang Province, China. After being disinfected with a solution of $0.1 \%$ (v/v) sodium hypochlorite for $1 \mathrm{~min}$, the fruits were rinsed with tap water and air-dried at room temperature $\left(20^{\circ} \mathrm{C}\right)$ prior to experiments.

\subsection{Yeasts}

The Tibetan yeasts for screening were provided by the Key Laboratory of Dairy Biotechnology and Engineering, Ministry of Education (Inner Mongolia Autonomous Region, China). They were isolated from yak yoghourt, identified by large-subunit (26S) ribosomal DNA (rDNA) D1/D2 domain sequence analysis, stored in ampoule tubes in lyophilized form at $-80{ }^{\circ} \mathrm{C}$, and activated on nutrient yeast dextrose agar (NYDA: $8 \mathrm{~g}$ nutrient broth, $5 \mathrm{~g}$ yeast extract, $10 \mathrm{~g}$ glucose, and $20 \mathrm{~g}$ agar in $1 \mathrm{~L}$ of distilled water) for two generations at $28{ }^{\circ} \mathrm{C}$ in the dark. Before the experiments, yeasts were inoculated by immersing a loop in $50 \mathrm{ml}$ NYD broth (NYDA without agar) and incubated at $28^{\circ} \mathrm{C}$ on a rotary shaker at $200 \mathrm{r} / \mathrm{min}$ for $24 \mathrm{~h}$. To remove the medium, the cells were centrifuged at $3500 \mathrm{~g}$ for $10 \mathrm{~min}$ and rinsed twice in sterile distilled water. Then, the pellets were re-suspended in sterile distilled water and adjusted to the required concentrations by counting cells with a hemocytometer.

\subsection{Pathogen}

$P$. expansum was originally isolated from symptomatic pear fruits. The pathogen was cultured in a test tube with potato dextrose agar (PDA; consisting of $200 \mathrm{ml}$ boiled potato extract, $20 \mathrm{~g}$ glucose, and $20 \mathrm{~g}$ agar in $1 \mathrm{~L}$ of distilled water) at $28^{\circ} \mathrm{C}$ for $7 \mathrm{~d}$. Conidia were removed by rubbing the surface of the medium with a bacteriological loop and suspending the loop in sterile distilled water. The final spore concentration was adjusted to $1 \times 10^{4}$ spores $/ \mathrm{ml}$ by use of a hemocytometer.

\subsection{Preliminary screening of Tibetan yeasts to control blue mold of pears}

Preliminary screening of Tibetan yeasts for antagonistic activity was based on their ability to inhibit the infection of pear fruit by $P$. expansum. The biocontrol activities of 20 yeast isolates from Tibetan fermented products were evaluated in vivo in the pear fruits at $20{ }^{\circ} \mathrm{C}$, according to the method described by Wilson et al. (1993). The fruits were wounded with a sterile cork-borer ( $5 \mathrm{~mm}$ diameter $\times 3 \mathrm{~mm}$ deep) and six wounds were bored on each pear. An aliquot $(50 \mu \mathrm{l})$ of the yeast cell suspensions in sterile distilled water at a concentration of $1 \times 10^{9}$ cells $/ \mathrm{ml}$ was inoculated into each wound, while the same volume of sterile distilled water was applied as a control. Each wound was dried at room temperature for about $3 \mathrm{~h}$, and then injected with $30 \mu \mathrm{l}$ of $P$. expansum spore suspension $\left(1 \times 10^{4}\right.$ spores $\left./ \mathrm{ml}\right)$. Then the samples were kept in enclosed plastic trays so as to maintain a high relative humidity at $20{ }^{\circ} \mathrm{C}$ in dark. Each yeast treatment consisted of three replicates, each consisting of 12 fruits. The whole experiment was performed twice. 
The decay incidence and lesion diameter on the treated pears were observed on the third day. Inhibition rates were calculated from the results using the following formulas: $\mathrm{DI}=\left(N_{\mathrm{C}}-N_{\mathrm{T}}\right) / N_{\mathrm{C}} \times 100 \%$ and $\mathrm{LI}=\left(d_{\mathrm{C}}-d_{\mathrm{T}}\right) / d_{\mathrm{C}} \times$ $100 \%$, where DI is decay inhibition $(\%), N_{\mathrm{C}}$ is the number of decay wounds for the control, and $N_{\mathrm{T}}$ is the number of decay wounds for the treatment; LI is lesion diameter inhibition $(\%), d_{\mathrm{C}}$ is lesion diameter of decay wounds for the control, and $d_{\mathrm{T}}$ is lesion diameter of decay wounds for the treatment. Treatments that showed a decay incidence inhibition rate higher than $35 \%$ were selected and re-evaluated in further experiments.

\subsection{Further screening of selected Tibetan yeasts to control blue mold of pears}

Six most promising Tibetan yeasts (JZ1-1, DX1-2, NQ11-2, NQ4-2, DX2-2, and RKZ1-5) that showed a decay incidence inhibition rate higher than $35 \%$ were selected and re-evaluated. Pear fruits were wounded as described above, then $50 \mu \mathrm{l}$ of the selected Tibetan yeast suspensions were incubated into each wound at $1 \times 10^{8}$ cells $/ \mathrm{ml}$. After drying, the wounds were treated and kept as described previously. Each yeast treatment consisted of three replicates, each comprising 12 fruits. The experiment was conducted twice and results were reported as the percentage of decay incidence and the average lesion diameter: $I_{\mathrm{d}}=N / N_{\text {total }} \times 100 \%$ and $d=\left(d_{\text {total }} / N\right)$, where $I_{\mathrm{d}}$ is decay incidence $(\%), N$ is the number of decayed wounds, $N_{\text {total }}$ is the number of total wounds, $d$ is lesion diameter ( $\mathrm{mm})$, and $d_{\text {total }}$ is total lesion diameter. The yeasts that gave the lowest decay incidence compared with the control were selected for further research.

\subsection{Antagonistic efficacy of the selected strain of R. mucilaginosa}

The antagonistic efficacy of the selected strain of $R$. mucilaginosa (RKZ1-5) to $P$. expansum was evaluated on pears. The procedure was similar to that described in Section 2.4. Six wounds were made on each pear with a sterile cork-borer. $R$. mucilaginosa suspension $(50 \mu \mathrm{l})$ in sterile distilled water at $1 \times 10^{5}$, $1 \times 10^{6}, 1 \times 10^{7}, 1 \times 10^{8}$, or $1 \times 10^{9}$ cells $/ \mathrm{ml}$ were pipetted into each wound, respectively. The same volume of sterile distilled water was pipetted into wounds to be used as controls. After $3 \mathrm{~h}, 30 \mu \mathrm{l}$ of pathogen spores at $1 \times 10^{4}$ cells $/ \mathrm{ml}$ were inoculated into the wounds.
The pear samples were incubated as described in Section 2.4. The biocontrol activity was assessed $6 \mathrm{~d}$ after treatment. Each yeast treatment consisted of three replicates, each consisting of 12 fruits. The experiment was conducted twice.

\subsection{Antagonistic action of different preparations of $\boldsymbol{R}$. mucilaginosa to $P$. expansum on pears}

The pear fruits were wounded using the procedure described in Section 2.4. Based on the results of the experiments (Section 2.6), the most effective cell concentration of $R$. mucilaginosa antagonistic to $P$. expansum was $1 \times 10^{8}$ cells $/ \mathrm{ml}$ and this was used in further tests based on the following preparations: (1) $1 \times 10^{8}$ cells $/ \mathrm{ml}$ unwashed cell culture mixture (i.e. the yeast cells in the nutrient yeast broth medium); (2) $1 \times 10^{8}$ cells $/ \mathrm{ml}$ washed cell suspension (prepared as described in Section 2.4); (3) cell-free culture filtrate (made by filtering the supernatant of the centrifuged yeast culture medium through $0.22 \mu \mathrm{m}$ sterile Millipore filtration); (4) autoclaved cell culture (the $R$. mucilaginosa culture was sterilized by moist heat sterilization at $121^{\circ} \mathrm{C}$ for $20 \mathrm{~min}$ ); (5) Sterile distilled water was used as a control. After air-drying, the treated pear samples were stored as described in Section 2.4. Decay incidence and lesion diameter were recorded after $6 \mathrm{~d}$. Each yeast treatment consisted of three replicates, each consisting of 12 fruits. The whole experiment was conducted twice.

\subsection{Antagonistic action of different preparations of $R$. mucilaginosa to spore germination of $P$. ex- pansum in vitro}

The antagonistic action of $R$. mucilaginosa in vitro was also evaluated by recording pathogen spore germination in potato dextrose broth (PDB) in the presence of the antagonistic yeast. The following yeast preparations were added to the PDB: $100 \mu \mathrm{l}$ of (1) $1 \times 10^{8}$ cells $/ \mathrm{ml}$ unwashed yeast culture mixture; (2) $1 \times 10^{8}$ cells $/ \mathrm{ml}$ washed yeast suspension; (3) a cell-free culture filtrate; (4) autoclaved cell culture; (5) sterile distilled water as a control. They were pipetted into $15 \mathrm{ml}$ glass tubes each containing $5 \mathrm{ml}$ PDB. In parallel, the same volume of $P$. expansum suspension at $1 \times 10^{7}$ spores $/ \mathrm{ml}$ was added to each tube. All tubes were incubated in a rotary shaker (QYC 2102, Shanghai FUMA, China) at $150 \mathrm{r} / \mathrm{min}$ at $28^{\circ} \mathrm{C}$. After $18 \mathrm{~h}$, the germination rate of a volume containing about 200 spores of pathogen was measured 
under a light microscope, as described by Droby et al. (1998). Each treatment consisted of three replicates and the whole experiment was performed twice.

\subsection{Effects of $\boldsymbol{R}$. mucilaginosa on the quality of wounded pears}

To rapidly evaluate the effect of the antagonistic R. mucilaginosa yeast on the quality of pear fruits, freshly harvested fruits were wounded as described in Section 2.4 and two wounds were made parallel to each other (about $6 \mathrm{~cm}$ apart). Then, $50 \mu \mathrm{l}$ of $R$. $m u$ cilaginos $a$ at $1 \times 10^{8}$ cells $/ \mathrm{ml}$ was added to one wound, and sterile distilled water to the other as a control. Quality parameters were measured after $6 \mathrm{~d}$ of storage at $20{ }^{\circ} \mathrm{C}$ in dark. The treatment consisted of three replicates, each consisting of three fruits. The whole experiment was performed twice. Quality measurements were conducted as follows: (1) The total soluble solid (TSS) content of pear juice was determined using a hand refractometer and the results expressed as g TSS/100 g fruit weight (Porat et al., 1999). (2) The ascorbic acid content of each pear was determined by the 2,6-dichloroindophenol titrimetric method and results were expressed as mg ascorbic acid/100 g sample (Pérez et al., 1999). (3) Titratable acidity was measured by titrating pear juice obtained from $10 \mathrm{~g}$ of pear tissue and diluted with $100 \mathrm{ml}$ of distilled water to $\mathrm{pH} 8.1$ with $0.1 \mathrm{~mol} / \mathrm{ml} \mathrm{NaOH}$. Titratable acidity is expressed as the percentage of malic acid (Wszelaki and Mitcham, 2000).

\subsection{Population dynamics of $R$. mucilaginosa in pear wounds}

The pear fruits were prepared and wounded as described in Section 2.4 and three wounds were made on each pear. Then, the wounds were inoculated with $50 \mu$ of a washed $R$. mucilaginosa cell suspension at $1 \times 10^{6}, 1 \times 10^{7}$, and $1 \times 10^{8}$ cells $/ \mathrm{ml}$. After these treatments, the fruits were stored as described above. Tissue was taken from these pears using a sterile cork-borer (10 mm diameter $\times 5 \mathrm{~mm}$ deep) at different time points $(0,12,24,36,48,72$, and $96 \mathrm{~h})$. The samples were ground in $10 \mathrm{ml}$ of sterile water using a sterile mortar and pestle. A hemocytometer was used to count the yeast cells (Yu and Zheng, 2006). The treatment consisted of three replicates, each consisting of three pears. The whole experiment was performed twice, independently.

\subsection{Statistical analysis}

The data presented are means from one individual experiment, representative of two independent experiments with similar results. The data were analyzed by one-way analysis of variance (ANOVA) using the statistical software SPSS 20.0 (SPSS Inc., Chicago, Illinois, USA). When the analysis result was significant at the level of $P<0.05$, separation of means was performed using Duncan's multiple range tests. The data from each experiment were analyzed separately.

\section{Results}

\subsection{Preliminary screening of Tibetan yeasts to control blue mold of pears}

The antagonistic efficacy of all 20 strains of yeast isolated from Tibetan local fermented products to $P$. expansum on pear fruits was expressed by the inhibition rate of decay incidence and lesion diameter (Table 1). In terms of decay incidence, most of the yeast isolates had a clear biocontrol activity, while four strains (NQ5-1, DX5-2, JZ1-2, and DX1-1) promoted disease development and one strain (LM1-1) had no significant effect. Among the fifteen yeasts with a positive effect, six strains (NQ 4-2, DX1-2, NQ11-2, JZ1-1, DX2-2, and RKZ1-5) inhibited fruit infection by more than $35 \%$ and one of them (RKZ1-5) almost completely inhibited the disease (Table 1). Almost all the yeast isolates inhibited the development of decay and R. mucilaginosa (RKZ1-5) was the most effective. The yeast isolates showing an inhibition of infection more than $35 \%$ were chosen for further screening.

\subsection{Further screening of selected Tibetan yeasts to control blue mold of pears}

Results from further evaluation of six Tibetan yeasts, selected as reported in Section 3.1, are shown in Table 2. At the common concentration of the antagonist of $1 \times 10^{8}$ cells $/ \mathrm{ml}$, the yeast isolate RKZ1-5 exhibited a significantly higher biocontrol activity in terms of decay incidence than the other five yeast strains. As regards lesion diameters, almost all six yeasts displayed protection, but RKZ1-5 was still the best. Based on these results, the yeast $R$. mucilaginosa was selected for further study. 
Table 1 Inhibition activity of screened Tibetan yeast isolates on blue mold of pears in vivo after $6 \mathrm{~d}$ of incubation

\begin{tabular}{|c|c|c|}
\hline $\begin{array}{l}\text { Tibetan yeasts from } \\
\text { fermented products }\end{array}$ & $\begin{array}{c}\text { Decay incidence } \\
\text { inhibition rate }(\%)\end{array}$ & $\begin{array}{c}\text { Lesion diameter } \\
\text { inhibition rate }(\%)\end{array}$ \\
\hline Control & $0^{\text {ef }}$ & $0^{\mathrm{j}}$ \\
\hline Issatchenkia orientalis (JZ10-1) & $23.38 \pm 43.29^{\text {cde }}$ & $52.73 \pm 20.93^{\text {cdefg }}$ \\
\hline Issatchenkia orientalis (NQ5-1) & $-36.61 \pm 3.28^{\mathrm{g}}$ & $26.75 \pm 0.08^{\mathrm{hi}}$ \\
\hline Issatchenkia orientalis (DX5-2) & $-19.94 \pm 19.94^{\mathrm{fg}}$ & $38.60 \pm 3.96^{\mathrm{efgh}}$ \\
\hline Pichia fermentans (JZ1-1) & $44.44 \pm 11.98^{\mathrm{bc}}$ & $68.79 \pm 8.47^{\mathrm{bcd}}$ \\
\hline Pichia membranifaciens (JZ5-8) & $19.84 \pm 21.60^{\text {cde }}$ & $50.94 \pm 11.15^{\text {defg }}$ \\
\hline Rhodotorula mucilaginosa (RKZ1-5) & $100^{\mathrm{a}}$ & $100^{\mathrm{a}}$ \\
\hline Geotrichum sp. (JZ2-1) & $0^{\operatorname{def}}$ & $13.72 \pm 1.33^{\mathrm{ij}}$ \\
\hline Pseudozyma sp. (DX4-2) & $11.11 \pm 11.11^{\text {cdef }}$ & $36.12 \pm 7.65^{\mathrm{fgh}}$ \\
\hline Yarrowia lipolytica (JZ7-2) & $18.52 \pm 16.97^{\text {cde }}$ & $54.29 \pm 11.69^{\text {cdef }}$ \\
\hline Candida zeylanoides (DX2-2) & $59.26 \pm 12.83^{\mathrm{b}}$ & $78.68 \pm 5.18^{\mathrm{b}}$ \\
\hline Torulaspora delbrueckii (JZ3-1) & $22.22 \pm 22.22^{\mathrm{cde}}$ & $50.88 \pm 8.99^{\text {defg }}$ \\
\hline Torulaspora delbrueckii (NQ4-2) & $37.04 \pm 16.97^{\mathrm{bcd}}$ & $65.34 \pm 5.69^{\mathrm{bcd}}$ \\
\hline Torulaspora delbrueckii (DX6-4) & $18.52 \pm 6.42^{\text {cde }}$ & $55.20 \pm 1.52^{\text {cde }}$ \\
\hline Pichia fermentans (NQ11-2) & $43.98 \pm 37.69^{\mathrm{bc}}$ & $71.30 \pm 20.31^{\mathrm{bc}}$ \\
\hline Pichia fermentans (DX1-2) & $38.89 \pm 34.70^{\mathrm{bc}}$ & $65.14 \pm 6.17^{\text {bd }}$ \\
\hline Saccharomyces cerevisiae (JZ1-2) & $-4.17 \pm 7.22^{\text {efg }}$ & $13.33 \pm 6.40^{\mathrm{ij}}$ \\
\hline Saccharomyces cerevisiae (DX1-1) & $-4.17 \pm 7.22^{\text {efg }}$ & $5.52 \pm 14.97^{\mathrm{j}}$ \\
\hline Saccharomyces cerevisiae (LM1-1) & $0^{\mathrm{def}}$ & $26.23 \pm 5.97^{\mathrm{hi}}$ \\
\hline Kluyveromyces marxianus (NQ10-2) & $7.41 \pm 12.83^{\text {cdef }}$ & $34.52 \pm 12.01^{\mathrm{gh}}$ \\
\hline Kluyveromyces marxianus (DX3-3) & $8.46 \pm 7.50^{\text {cdef }}$ & $28.46 \pm 11.10^{\mathrm{hi}}$ \\
\hline
\end{tabular}

JZ and RKZ were obtained from the Xigaze area of Tibet; NQ and LM from Nagqu County and DX from the Damxung County, Tibet. The uppercase letters combined with numbers stand for the strain number. The concentration of washed Tibetan yeast suspension incubated into wounds on pear fruits was $1 \times 10^{9}$ cells $/ \mathrm{ml}$. The pathogen conidial suspension was added into wounds at $1 \times 10^{4} \mathrm{spores} / \mathrm{ml}$. Results are presented as mean \pm standard deviation (SD) $(n=3)$. In the two columns of inhibition rates, mean values followed by different letters are statistically different at $P<0.05$ according to Duncan's multiple range test

Table 2 Antagonistic activity of six selected Tibetan yeasts on blue mold of pears in vivo

\begin{tabular}{lcc}
\hline \multicolumn{1}{c}{ Selected Tibetan yeasts } & Decay incidence (\%) & Lesion diameter $(\mathrm{mm})$ \\
\hline Control & $100^{\mathrm{a}}$ & $20.80 \pm 1.98^{\mathrm{a}}$ \\
Pichia fermentans (JZ1-1) & $100^{\mathrm{a}}$ & $13.42 \pm 1.84^{\mathrm{c}}$ \\
Pichia fermentans (DX1-2) & $100^{\mathrm{a}}$ & $13.40 \pm 1.05^{\mathrm{c}}$ \\
Pichia fermentans (NQ11-2) & $97.22 \pm 4.81^{\mathrm{a}}$ & $12.85 \pm 1.26^{\mathrm{c}}$ \\
Torulaspora delbrueckii (NQ4-2) & $100^{\mathrm{a}}$ & $17.04 \pm 1.80^{\mathrm{b}}$ \\
Candida zeylanoides (DX2-2) & $100^{\mathrm{a}}$ & $15.73 \pm 1.84^{\mathrm{bc}}$ \\
Rhodotorula mucilaginosa (RKZ1-5) & $76.48 \pm 15.87^{\mathrm{b}}$ & $8.16 \pm 1.58^{\mathrm{d}}$ \\
\hline
\end{tabular}

JZ and RKZ were obtained from the Xigaze area of Tibet; NQ from Nagqu County and DX from Damxung County, Tibet. The uppercase letters combined with numbers stand for the strain number. The concentration of washed Tibetan yeast suspension incubated into wounds on pear fruits was $1 \times 10^{8}$ cells $/ \mathrm{ml}$. The pathogen conidial suspension was added into wounds at $1 \times 10^{4}$ spores $/ \mathrm{ml}$. Results are presented as mean $\pm \mathrm{SD}(n=3)$. Within a column, mean values followed by different letters are statistically different at $P<0.05$ according to Duncan's multiple range test

\subsection{Antagonistic efficacy of selected yeast strain $R$. mucilaginosa to $P$. expansum on pear fruits}

The results of the antagonistic efficacy of $R . m u$ cilaginosa at different concentrations to $P$. expansum on pear fruits after $6 \mathrm{~d}$ of incubation are shown in Fig. 1a. Compared with the control, the incidence of decay was significantly reduced $(P<0.05)$ by $R$. mucilaginosa except at the concentration of $1 \times 10^{5} \mathrm{cells} / \mathrm{ml}$. The higher the concentration of the yeast, the lower 
was the incidence of decay. The highest biocontrol activity (the least decay) was obtained at the higher concentrations of $1 \times 10^{8}$ cells $/ \mathrm{ml}(16.7 \%$ decay $)$ and $1 \times 10^{9}$ cells $/ \mathrm{ml}$ ( $2.8 \%$ decay) (Fig. 1a). The effect of $R$. mucilaginosa at different concentrations on lesion diameter was similar. However, the antagonist also had obvious efficacy on lesion diameter $(P<0.05)$


Fig. 1 Antagonistic efficacy of $R$. mucilaginosa to $P$. expansum on pear fruits

Decay incidence (a) and lesion diameter (b) were measured after $6 \mathrm{~d}$ storage at $20{ }^{\circ} \mathrm{C}$. (c) The statistic of incidence trend was made by the decay incidence of each day. Data are presented as mean $\pm \mathrm{SD}(n=3)$. Data in columns with the different letters are significantly different at $P<0.05$ according to Duncan's multiple range test at the low concentration of $1 \times 10^{5}$ cells/ml (Fig. 1b). The trend in the incidence of decay also indicated that the biocontrol activity gradually weakened with storage time, but at the high concentrations of $1 \times 10^{8}$ and $1 \times 10^{9}$ cells $/ \mathrm{ml}$, the rise in the incidence of decay was much slower than that at lower concentrations (Fig. 1c).

\subsection{Antagonistic activity of different preparations of $R$. mucilaginosa in vivo}

The biocontrol activity of different preparations of $R$. mucilaginosa is shown in Fig. 2. The washed cell suspension had higher antagonistic activity $(41.7 \%)$ to control blue mold of pear fruits than the other three preparations (Fig. 2a). The same result was found for the lesion diameter. The washed cell suspension produced the smallest lesion diameter of $4.6 \mathrm{~mm}$ (Fig. 2b). The autoclaved cell culture had hardly any antagonistic activity.
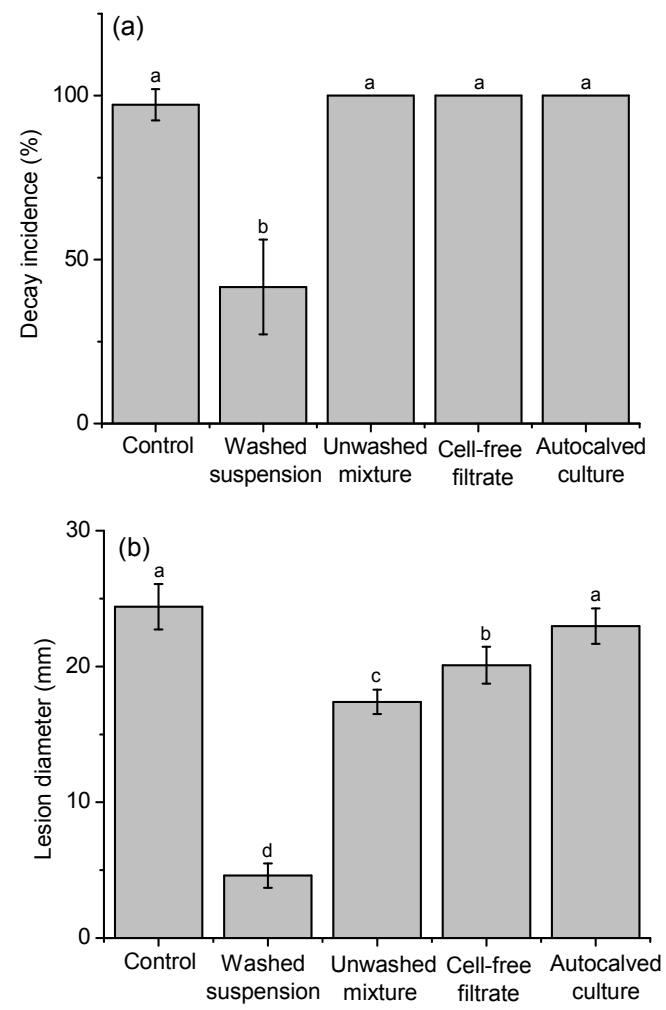

Fig. 2 Antagonistic activity of different preparations of $R$. mucilaginosa in vivo

Decay incidence (a) and lesion diameter (b) were measured after $6 \mathrm{~d}$ of storage at $20{ }^{\circ} \mathrm{C}$. Data are presented as mean $\pm \mathrm{SD}(n=3)$. Data in columns with the different letters are significantly different at $P<0.05$ according to Duncan's multiple range test 


\subsection{Inhibition of spore germination of $P$. expan- sum by different preparations of $R$. mucilaginosa}

The biocontrol activity of different preparations of $R$. mucilaginosa in vitro is shown in Fig. 3. Both washed and unwashed yeast cell suspensions were most effective at inhibiting spore germination in $P$. expansum, and the inhibition rates were $54.0 \%$ and $54.7 \%$, respectively. The cell-free culture filtrate and autoclaved cell culture had hardly any effect on $P$. expansum spore germination, but promoted growth of the pathogen in PDB.

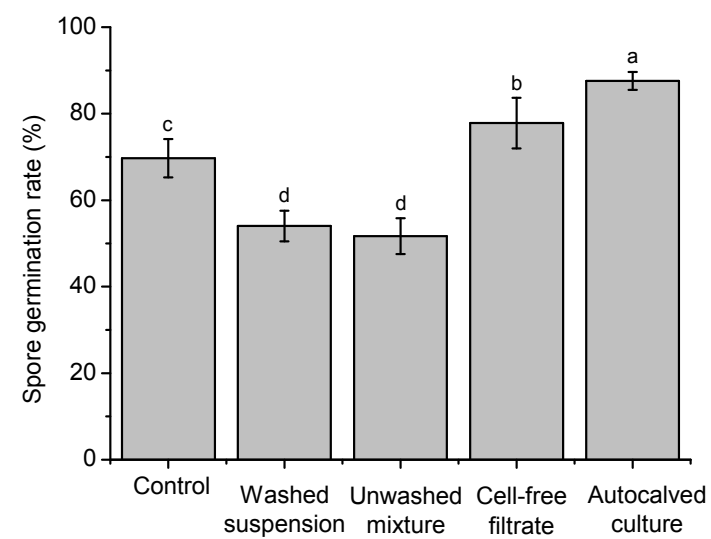

Fig. 3 Inhibition of spore germination by $R$. mucilaginosa in vitro

Spore germination (percentage of germinated spores calculated from counts at least 200 spores) was measured after $18 \mathrm{~h}$ of incubation. Data are presented as mean $\pm \mathrm{SD}(n=3)$. Data in columns with the different letters are significantly different at $P<0.05$ according to Duncan's multiple range test

\subsection{Effects of $\boldsymbol{R}$. mucilaginosa on fruit quality}

The results of quality tests on pear fruits are shown in Table 3 . After $6 \mathrm{~d}$ storage at $20^{\circ} \mathrm{C}$, although the titratable acidity of treated fruits increased $(P<0.05), R$. mucilaginosa had hardly any effect on the TSS or ascorbic acid content.

Table 3 Effects of $\boldsymbol{R}$. mucilaginosa on pear fruit quality

\begin{tabular}{lccc}
\hline Treatment & $\begin{array}{c}\text { TSS } \\
(\%)\end{array}$ & $\begin{array}{c}\text { Titratable acidity } \\
(\% \text { malic acid })\end{array}$ & $\begin{array}{c}\text { Ascorbic acid } \\
(\mathrm{mg} / 100 \mathrm{~g})\end{array}$ \\
\hline Control & $11.44 \pm 0.74^{\mathrm{a}}$ & $0.061 \pm 0.0055^{\mathrm{b}}$ & $2.70 \pm 0.08^{\mathrm{a}}$ \\
Antagonist & $11.43 \pm 0.67^{\mathrm{a}}$ & $0.079 \pm 0.0018^{\mathrm{a}}$ & $2.53 \pm 0.21^{\mathrm{a}}$ \\
\hline
\end{tabular}

Results are presented as mean \pm SD $(n=3)$. Within each column, mean values followed by different letters are statistically different at $P<0.05$ according to Duncan's multiple range test

\subsection{Population dynamics of $\boldsymbol{R}$. mucilaginosa in pear wounds}

The population dynamics of $R$. mucilaginosa in pear fruit wounds at $20{ }^{\circ} \mathrm{C}$ is shown in Fig. 4. The yeast grew rapidly in the first $24 \mathrm{~h}$ at all three concentrations $\left(1 \times 10^{6}, 1 \times 10^{7}\right.$, and $1 \times 10^{8}$ cells $\left./ \mathrm{ml}\right)$. The higher the concentration, the faster was the growth. At $48 \mathrm{~h}$ of incubation, the population dynamics at three different concentrations reached maximum densities of $8.63 \times 10^{6}, 1.71 \times 10^{7}$, and $3.82 \times 10^{7}$ cells $/ \mathrm{ml}$, respectively. As time went on, the populations gradually decreased, falling to $4.47 \times 10^{6}, 5.46 \times 10^{6}$ and $1.63 \times$ $10^{7}$ cells/ml, respectively, after $96 \mathrm{~h}$.

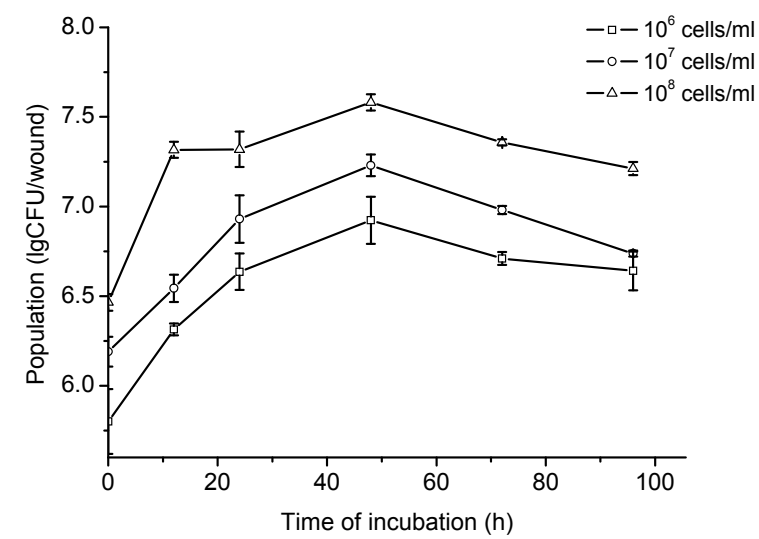

Fig. 4 Population dynamics of $R$. mucilaginosa in pear wounds at $20^{\circ} \mathrm{C}$

The population density was measured at $12,24,36,48,72$, and $96 \mathrm{~h}$. Data are presented as mean $\pm \mathrm{SD}(n=3)$

\section{Discussion}

The use of microbial antagonists in the control of postharvest decay has been reported as an effective alternative to the use of chemical fungicides (Droby et al., 2009; Wilson et al., 2011). Antagonistic yeast is regarded as the most promising biocontrol agent since the inhibitory mechanism does not depend mainly on the production of antibiotics (Droby et al., 1998; Zhang et al., 2005; 2008; Manso and Nunes, 2011). Antagonistic yeasts are generally isolated from fruit surfaces and fruit wounds (Wilson and Wisniewski, 1989; Wilson et al., 1993). The sources have recently been expended to other environments, such as sea water (Wang et al., 2010) and Antarctic soil (Vero et al., 2013). The main reason for exploring these new sources is that the yeasts in specific geographic areas 
may have unique characteristics and perhaps be more effective as biocontrol agents against fruit pathogens (Sayago et al., 2012; Vero et al., 2013). Based on this, our study focused on screening antagonistic yeast from Tibet.

Through a preliminary screening test, $R$. mucilaginosa was screened out from 20 strains of yeasts isolated from local fermented products in Tibet. All the yeast isolates were identified and provided by the Key Laboratory of Dairy Biotechnology and Engineering, Ministry of Education (Inner Mongolia, China). The biocontrol activity of $R$. mucilaginosa was confirmed in further screening tests (Table 2). Although this kind of yeast has been reported previously to protect fruits after harvest (Li et al., 2011; Robiglio et al., 2011), this is the first study of the use of $R$. mucilaginosa from Tibet to control the blue mold of pear fruits.

From the detailed antagonistic efficacy trials, the results in Fig. 4 indicated that the biocontrol activity of $R$. mucilaginosa gradually improves with increasing concentration. The optimum concentration was $1 \times 10^{8}$ cells $/ \mathrm{ml}$, because at this concentration biocontrol activity was similar to that at $1 \times 10^{9}$ cells $/ \mathrm{ml}$. A similar phenomenon was also found in other studies of Rhodotorula yeasts (Castoria et al., 2005; Dal Bello et al., 2008; Zhang et al., 2008; Robiglio et al., 2011). Generally, competition with pathogen for nutrients and space in the wounds of fruits is recognized as the main biocontrol mechanism of antagonistic yeast (Ippolito and Nigro, 2000; Sharma et al., 2009), so the population dynamics of $R$. mucilaginosa in wounds of pear fruits was used to study its biocontrol mechanism. The results were consistent with this theory and not only showed that $R$. mucilaginosa could rapidly colonize and grow on the pear fruits, but also explained why the higher concentration could lead to better biocontrol activity.

To further investigate the control mechanism of R. mucilaginosa against the blue mold of pear fruits, the efficacy of the yeasts in different preparations was evaluated in vivo and in vitro. According to the results of the in vivo test (Fig. 2), the washed cell suspension had the best biocontrol activity, while the other three preparations hardly had any effect on the incidence of blue mold of pear fruits. Among the other three preparations, the unwashed cell culture mixture and cell-free culture filtrate inhibited the lesion expansion of pear fruits at different levels, and the unwashed cell culture mixture had the better activity. This finding indicates that the competition of $R$. mucilaginosa for nutrients and space on pear fruits was weakened when the yeast was in a suspension full of nutrients (Zhang et al., 2003; Bencheqroun et al., 2007). It also demonstrates that competition for nutrients in fruit wounds is an important mechanism of yeast antagonism. The cell-free culture filtrate had some inhibiting effects on the expansion of lesions in pear fruits, showing that $R$. mucilaginosa may produce some substances that inhibit the pathogen, such as hydrolases (Zhang et al., 2011; 2012; Barbey et al., 2012; Calvo-Garrido et al., 2013; Hershkovitz et al., 2013) or rhodotorulic acid (Calvente et al., 1999; Sansone et al., 2005). The result of the in vitro test (Fig. 3) showed that both the washed and unwashed cell culture mixtures inhibited pathogen spore germination effectively. There may be other mechanisms of action by which $R$. mucilaginosa can control blue mold in vitro. In any case, both test results indicated that the washed cell suspension of $R$. mucilaginosa had the best biocontrol activity among the four different preparations and the major mechanism of action is likely to be the competition with pathogen for nutrients and space in wounds of the pear fruits.

The study also showed that $R$. mucilaginosa had almost no detrimental effects on the quality of pear fruits during storage at room temperature. Although the titratable acidity increased above controls after treatment, there was no apparent damage to the pears. What is more, the TSS or ascorbic acid content was not significantly changed by $R$. mucilaginosa .

In conclusion, the study indicated that the yeast $R$. mucilaginosa isolated from Tibetan fermented products had biocontrol activity against the blue mold of pear fruits during postharvest storage. Through further study, its potential as a new kind of antagonistic yeast agent to protect the pear fruits from decay can be explored.

\section{Acknowledgements}

We thank the supports by Prof. He-ping ZHANG from the Key Laboratory of Dairy Biotechnology and Engineering, Ministry of Education (Inner Mongolia Autonomous Region, China) and the President and CEO, Prof. Charles WILSON, of Wilson Associates International LLC for their support. 


\section{Compliance with ethics guidelines}

Hao HU, Yang XU, Huang-ping LU, Rui XIAO, Xiao-dong ZHENG, and Ting YU declare that they have no conflict of interest.

This article does not contain any studies with human or animal subjects performed by any of the authors.

\section{References}

An, B., Li, B., Qin, G., et al., 2012. Exogenous calcium improves viability of biocontrol yeasts under heat stress by reducing ROS accumulation and oxidative damage of cellular protein. Curr. Microbiol., 65(2):122-127. [doi:10. 1007/s00284-012-0133-4]

Barbey, C., Crepin, A., Cirou, A., et al., 2012. Catabolic pathway of gamma-caprolactone in the biocontrol agent Rhodococcus erythropolis. J. Proteome Res., 11(1):206216. [doi:10.1021/pr200936q]

Bencheqroun, S.K., Baji, M., Massart, S., et al., 2007. In vitro and in situ study of postharvest apple blue mold biocontrol by Aureobasidium pullulans: evidence for the involvement of competition for nutrients. Postharvest Biol. Technol., 46(2):128-135. [doi:10.1016/j.postharvbio. 2007.05.005]

Calvente, V., Benuzzi, D., de Tosetti, M.I.S., 1999. Antagonistic action of siderophores from Rhodotorula glutinis upon the postharvest pathogen Penicillium expansum. Int. Biodeterior. Biodegrad., 43(4):167-172. [doi:10.1016/S0964-8305(99)00046-3]

Calvo-Garrido, C., Viñas, I., Elmer, P., et al., 2013. Candida sake CPA-1 and other biologically based products as potential control strategies to reduce sour rot of grapes. Lett. Appl. Microbiol., 57(4):356-361. [doi:10.1111/lam. 12121]

Castoria, R., Morena, V., Caputo, L., et al., 2005. Effect of the biocontrol yeast Rhodotorula glutinis strain LS11 on patulin accumulation in stored apples. Phytopathology, 95(11):1271-1278. [doi:10.1094/PHYTO-95-1271]

Dal Bello, G., Monaco, C.M., Rollan, M.C., et al., 2008. Biocontrol of postharvest grey mould on tomato by yeasts J. Phytopathol., 156(5):257-263. [doi:10.1111/j.14390434.2007.01351.x]

D'Aquino, S., Fadda, A., Barberis, A., et al., 2013. Combined effects of potassium sorbate, hot water and thiabendazole against green mould of citrus fruit and residue levels. Food Chem., 141(2):858-864. [doi:10.1016/j.foodchem. 2013.03.083]

Droby, S., Cohen, L., Daus, A., et al., 1998. Commercial testing of aspire: a yeast preparation for the biological control of postharvest decay of citrus. Biol. Control, 12(2):97-101. [doi:10.1006/bcon.1998.0615]

Droby, S., Wisniewski, M., Macarisin, D., et al., 2009. Twenty years of postharvest biocontrol research: is it time for a new paradigm? Postharvest Biol. Technol., 52(2):137-145. [doi:10.1016/j.postharvbio.2008.11.009]

Hershkovitz, V., Sela, N., Taha-Salaime, L., et al., 2013. De-novo assembly and characterization of the transcriptome of Metschnikowia fructicola reveals differences in gene expression following interaction with Penicillium digitatum and grapefruit peel. BMC Genomics, 14(1):168. [doi:10. 1186/1471-2164-14-168]

Ippolito, A., Nigro, F., 2000. Impact of preharvest application of biological control agents on postharvest diseases of fresh fruits and vegetables. Crop Prot., 19(8-10):715-723. [doi:10.1016/S0261-2194(00)00095-8]

Jamalizadeh, M., 2011. A review of mechanisms of action of biological control organisms against post-harvest fruit spoilage. EPPO Bull., 41(1):65-71. [doi:10.1111/j.13652338.2011.02438.x]

Janisiewicz, W.J., Korsten, L., 2002. Biological control of postharvest diseases of fruits. Annu. Rev. Phytopathol., 40: 411-441. [doi:10.1146/annurev.phyto.40.120401.130158]

Janisiewicz, W.J., Jurick, W.M., Peter, K.A., et al., 2014. Yeasts associated with plums and their potential for controlling brown rot after harvest. Yeast, 31(6):207-218. [doi:10.1002/yea.3009]

Jurick, W.M., Vico, I., Gaskins, V.L., et al., 2010. Purification and biochemical characterization of polygalacturonase produced by Penicillium expansum during postharvest decay of 'Anjou' pear. Phytopathology, 100(1):42-48. [doi:10.1094/PHYTO-100-1-0042]

Lennox, C.L., Spotts, R.A., Booyse, M., 2004. Incidence of postharvest decay of 'd'Anjou' pear and control with a thiabendazole drench. Plant Dis., 88(5):474-478. [doi:10. 1094/PDIS.2004.88.5.474]

Li, R.P., Zhang, H.Y., Liu, W.M., et al., 2011. Biocontrol of postharvest gray and blue mold decay of apples with Rhodotorula mucilaginosa and possible mechanisms of action. Int. J. Food Microbiol., 146(2):151-156. [doi:10. 1016/j.ijfoodmicro.2011.02.015]

Liu, D., Zhang, D., Liu, G., et al., 2013. Influence of heat stress on leaf ultrastructure, photosynthetic performance, and ascorbate peroxidase gene expression of two pear cultivars (Pyrus pyrifolia). J. Zhejiang Univ.-Sci. B (Biomed. \& Biotechnol.), 14(12):1070-1083. [doi:10. 1631/jzus.B1300094]

Lu, H., Lu, L., Zeng, L., et al., 2014. Effect of chitin on the antagonistic activity of Rhodosporidium paludigenum against Penicillium expansum in apple fruit. Postharvest Biol. Technol., 92:9-15. [doi:10.1016/j.postharvbio.2014. 01.009]

Lutz, M.C., Robiglio, A., Sosa, M.C., et al., 2011. Two selection strategies of epiphytic native yeasts with potential biocontrol capacity against postharvest pear pathogens in Patagonia. In: Sánchez, E.E., Sugar, D., Webster, A.D. (Eds.), ISHS Acta Horticulturae 909: XI International Pear Symposium. Patagonia, Argentina, p.761-768.

Manso, T., Nunes, C., 2011. Metschnikowia andauensis as a new biocontrol agent of fruit postharvest diseases. Postharvest Biol. Technol., 61(1):64-71. [doi:10.1016/j. postharvbio.2011.02.004]

Pérez, A.G., Sanz, C., Rios, J.J., et al., 1999. Effects of ozone 
treatment on postharvest strawberry quality. J. Agric. Food Chem., 47(4):1652-1656. [doi:10.1021/jf9808291]

Porat, R., Weiss, B., Cohen, L., et al., 1999. Effects of ethylene and 1-methylcyclopropene on the postharvest qualities of 'Shamouti' oranges. Postharvest Biol. Technol., 15(2): 155-163. [doi:10.1016/S0925-5214(98)00079-9]

Robiglio, A., Sosa, M.C., Lutz, M.C., et al., 2011. Yeast biocontrol of fungal spoilage of pears stored at low temperature. Int. J. Food Microbiol., 147(3):211-216. [doi:10.1016/j.ijfoodmicro.2011.04.007]

Sanderson, P.G., Spotts, R.A., 1995. Postharvest decay of winter pear and apple fruit caused by species of Penicillium. Phytopathology, 85(1):103-110. [doi:10.1094/ Phyto-85-103]

Sansone, G., Rezza, I., Calvente, V., et al., 2005. Control of Botrytis cinerea strains resistant to iprodione in apple with rhodotorulic acid and yeasts. Postharvest Biol. Technol., 35(3):245-251. [doi:10.1016/j.postharvbio.2004. 09.005]

Sayago, J.E., Ordoñez, R.M., Kovacevich, L.N., et al., 2012. Antifungal activity of extracts of extremophile plants from the Argentine Puna to control citrus postharvest pathogens and green mold. Postharvest Biol. Technol., 67:19-24. [doi:10.1016/j.postharvbio.2011.12.011]

Sharma, R.R., Singh, D., Singh, R., 2009. Biological control of postharvest diseases of fruits and vegetables by microbial antagonists: a review. Biol. Control, 50(3):205-221. [doi:10.1016/j.biocontrol.2009.05.001]

Spadaro, D., Gullino, M.L., 2004. State of the art and future prospects of the biological control of postharvest fruit diseases. Int. J. Food Microbiol., 91(2):185-194. [doi:10. 1016/S0168-1605(03)00380-5]

Sugar, D., Basile, S.R., 2011. Orchard calcium and fungicide treatments mitigate effects of delayed postharvest fungicide applications for control of postharvest decay of pear fruit. Postharvest Biol. Technol., 60(1):52-56. [doi:10.1016/j.postharvbio.2010.11.007]

Vero, S., Garmendia, G., González, M.B., et al., 2013. Evaluation of yeasts obtained from Antarctic soil samples as biocontrol agents for the management of postharvest diseases of apple (Malus $\times$ domestica). FEMS Yeast Res., 13(2):189-199. [doi:10.1111/1567-1364.12021]

Wang, Y., Yu, T., Li, Y., et al., 2009. Postharvest biocontrol of Alternaria alternata in Chinese winter jujube by Rhodosporidium paludigenum. J. Appl. Microbiol., 107(5): 1492-1498. [doi:10.1111/j.1365-2672.2009.04330.x]

Wang, Y.F., Yu, T., Xia, J.D., et al., 2010. Biocontrol of postharvest gray mold of cherry tomatoes with the marine yeast Rhodosporidium paludigenum. Biol. Control, 53(2): 178-182. [doi:10.1016/j.biocontrol.2010.01.002]

Wang, Y.F., Tang, F., Xia, J.D., et al., 2011. A combination of marine yeast and food additive enhances preventive effects on postharvest decay of jujubes (Zizyphus jujuba). Food Chem., 125(3):835-840. [doi:10.1016/j.foodchem. 2010.09.032]

Wilson, C.L., Wisniewski, M.E., 1989. Biological control of postharvest diseases of fruits and vegetables: an emerging technology. Annu. Rev. Phytopathol., 27:425-441. [doi:10. 1146/annurev.py.27.090189.002233]

Wilson, C.L., Wisniewski, M.E., Biles, C.L., et al., 1991. Biological control of post-harvest diseases of fruits and vegetables: alternatives to synthetic fungicides. Crop Prot., 10(3):172-177. [doi:10.1016/0261-2194(91)90039-T]

Wilson, C.L., Wisniewski, M.E., Droby, S., et al., 1993. A selection strategy for microbial antagonists to control postharvest diseases of fruits and vegetables. Sci. Hort., 53(3):183-189. [doi:10.1016/0304-4238(93)90066-Y]

Wilson, C.L., Wisniewski, M., Droby, S., et al., 2011. Historical perspective on biological control of postharvest diseases-past, present, and future. In: Wisniewski, M., Droby, S. (Eds.), ISHS Acta Horticulturae 905: International Symposium on Biological Control of Postharvest Diseases: Challenges and Opportunities. Leesburg, VA, USA, p.23-28.

Wisniewski, M., Biles, C., Droby, S., et al., 1991. Mode of action of the postharvest biocontrol yeast, Pichia guilliermondii. I. Characterization of attachment to Botrytis cinerea. Physiol. Mol. Plant Pathol., 39(4): 245-258. [doi:10.1016/0885-5765(91)90033-E]

Wisniewski, M.E., Wilson, C.L., 1992. Biological-control of postharvest diseases of fruits and vegetables-recent advances. Hortscience, 27(2):94-98.

Wszelaki, A.L., Mitcham, E.J., 2000. Effects of superatmospheric oxygen on strawberry fruit quality and decay. Postharvest Biol. Technol., 20(2):125-133. [doi: 10.1016/S0925-5214(00)00135-6]

Xu, X.B., Chan, Z.L., Xu, Y., et al., 2008. Effect of Pichia membranaefaciens combined with salicylic acid on controlling brown rot in peach fruit and the mechanisms involved. J. Sci. Food Agric., 88(10):1786-1793. [doi:10. 1002/jsfa.3281]

Yu, T., Zheng, X.D., 2006. Salicylic acid enhances biocontrol efficacy of the antagonist Cryptococcus laurentii in apple fruit. J. Plant Growth Regul., 25(2):166-174. [doi:10. 1007/s00344-005-0077-z]

Yu, T., Yu, C., Chen, F.X., et al., 2012. Integrated control of blue mold in pear fruit by combined application of chitosan, a biocontrol yeast and calcium chloride. Postharvest Biol. Technol., 69:49-53. [doi:10.1016/j. postharvbio.2012.02.007]

Yue, X.Y., Liu, G.Q., Zong, Y., et al., 2014. Development of genic SSR markers from transcriptome sequencing of pear buds. J. Zhejiang Univ.-Sci. B (Biomed. \& Biotechnol.), 15(4):303-312. [doi:10.1631/jzus.B1300240]

Zhang, D.P., Spadaro, D., Valente, S., et al., 2011. Cloning, characterization and expression of an exo-1,3- $\beta$ glucanase gene from the antagonistic yeast, Pichia guilliermondii strain M8 against grey mold on apples. Biol. Control, 59(2):284-293. [doi:10.1016/j.biocontrol. 2011.06.018]

Zhang, D.P., Spadaro, D., Valente, S., et al., 2012. Cloning, 
characterization, expression and antifungal activity of an alkaline serine protease of Aureobasidium pullulans PL5 involved in the biological control of postharvest pathogens. Int. J. Food Microbiol., 153(3):453-464. [doi: 10.1016/j.ijfoodmicro.2011.12.016]

Zhang, H.Y., Zheng, X.D., Xi, Y.F., 2003. Biocontrol of postharvest blue mould rot of pear by Cryptococcus laurentii. J. Hortic. Sci. Biotechnol., 78(6):888-893.

Zhang, H.Y., Zheng, X.D., Fu, C.X., et al., 2005. Postharvest biological control of gray mold rot of pear with Cryptococcus laurentii. Postharvest Biol. Technol., 35(1): 79-86. [doi:10.1016/j.postharvbio.2004.03.011]

Zhang, H.Y., Zheng, X.D., Yu, T., 2007. Biological control of postharvest diseases of peach with Cryptococcus laurentii. Food Control, 18(4):287-291. [doi:10.1016/j.foodcont. 2005.10.007]

Zhang, H.Y., Wang, L., Dong, Y., et al., 2008. Control of postharvest pear diseases using Rhodotorula glutinis and its effects on postharvest quality parameters. Int. J. Food Microbiol., 126(1-2):167-171. [doi:10.1016/j.ijfoodmicro. 2008.05.018]

Zhao, J., Xue, Q.H., Shen, G.H., et al., 2012. Evaluation of Streptomyces spp. for biocontrol of gummy stem blight (Didymella bryoniae) and growth promotion of Cucumis melo L. Biocontrol Sci. Technol., 22(1):23-37. [doi:10. 1080/09583157.2011.636481]

\section{中文概要}

题 目: 西藏发酵制品中拮抗酵母对水晶梨青霉病的防治 效果研究

目 的: 从西藏发酵制品中分离篮选出对水晶梨采后青霉 病具有较好防治效果的拮抗酵母, 并对其作用机 理进行研究。

创新点: 首次从西藏发酵制品中篮选得到一株对水晶梨采 后青霉病具有较好防治效果的拮抗酵母 Rhodotorula mucilaginosa, 并对其作用机理进行 了初步研究。

方 法: 采用水晶梨果实体内篮选的方法, 经过初篮与复 筛, 确定具有较好生防效果的拮抗酵母; 通过对 篮选所得拮抗酵母不同浓度、不同处理液的生防 效果, 果实伤口处生长动态, 以及对梨果实采后 品质影响的研究, 初步探讨西藏发酵制品中拮抗 酵母的生防作用机理。

结 论: 从西藏发酵制品中筛选得到一株拮抗酵母 $R$. mucilaginosa, 其对水晶梨采后青霉病具有较好的 生物防治效果。研究结果发现其主要作用机理为 在果实伤口处与病原菌的营养与空间竞争。通过 进一步研究, 可开发为梨果实采后病害防治的新 型生物保鲜剂。

关键词：生物防治; 采后; Rhodotorula mucilaginosa; 西 藏发酵制品; 水晶梨 